\title{
What's the use of socio-economic rights in a constitution? - Taking a look at the South African experience
}

\author{
By Mirja Trilsch, Montreal*
}

\section{Introduction}

"Our Constitution protects the weak, the marginalised, the socially outcast, and the victims of prejudice and stereotyping. It is only when these groups are protected that we can be secure that our own rights are protected."

Over the last 15 years, ${ }^{2}$ South Africa has become a role model for the domestic implementation and enforcement of constitutionally enshrined socio-economic rights. While drafting what is nowadays considered to be the most progressive constitution of modern times, ${ }^{3}$ South Africa chose to translate its aspirations for social justice and social welfare into justiciable constitutional guarantees. Protecting the weak, the marginalised and the socially outcast thus became a matter of constitutional rights: housing, health care, food, water and social security.

As far as socio-economic rights are concerned, it can safely be said that the constitutional development in South Africa defied all odds. Not only have these rights traditionally been considered to be non-justiciable, they also seemed irreconcilable with British constitutionalism and its core element, that is, parliamentary sovereignty as previously championed in South Africa. Moreover, South Africa was and remains a country facing numerous economic and social challenges and therefore hardly appeared to be able to fulfill the costly demands expected to originate from social rights litigation.

The present article is intended to provide a general understanding of the socio-economic rights contained in the South African Constitution. To this end, it will review the historical developments leading to their inclusion, the wording of the relevant provisions as well as their judicial interpretation by the Constitutional Court. It will also explain how the

* Mirja Trilsch, LL.M. (McGill), Lecturer in Law, Université du Québec à Montréal (UQÀM), Montreal, Canada. Email: trilsch.mirja@uqam.ca.

1 Hoffmann $v$ South African Airways, 28 September 2000, Case CCT 17/00, 2001 (1) SA 1 (CC), 2000 (11) BCLR 1211 (CC), para. 34.

In fact, ever since the adoption of the Interim Constitution of the Republic of South Africa, Act 200 of 1993, date of commencement 27 April 1994 [hereinafter: Interim Constitution of 1993].

3 Constitution of the Republic of South Africa, 1996, date of commencement 4 February 1997. The text of the Constitution in its current version after the Sixteenth Amendment Act of 2009 is available on the website of the Constitutional Court of South Africa (www.constitutionalcourt.org.za/ site/theconstitution/thetext, last visited 09/2009). 
Court has ventured into developing a methodology for reviewing governmental compliance with the Constitution's socio-economic guarantees. This constitutes a novelty in human rights jurisprudence and invites some reflection on the question of what is, after all, the issue with socio-economic rights in a constitution.

\section{The inclusion of socio-economic rights in the South African Constitution}

\subsection{Background}

While most national constitutions bear some amount of evidence of their country's past, this is particularly true for the South African Constitution, which must be observed in light of the era of Apartheid preceding its adoption and the decades-long struggle to overcome this oppressive regime. Its preamble attests to the people's desire to "[h]eal the divisions of the past and establish a society based on democratic values, social justice and fundamental human rights." "4 The drafting of this Constitution, however, presented quite a challenge in relation to the country's pre-existing trauma, which made the transparency of the drafting process and the legitimacy of the document resulting from it, of paramount importance.

The making of the Constitution, therefore, was not a singular act, but consisted in a prudent exercise sometimes referred to as "transformative constitutionalism". 5 It was marked by an intermediate stage involving the inauguration of an interim Constitution, ${ }^{6}$ and two core safeguards to ensure that the substance of the final Constitution lived up to its intended standard: the so-called Constitutional Principles and the Certification Procedure. The former Principles were contained in Annex IV of the Interim Constitution and were meant to provide a general framework of thirty-four politically negotiated principles that had to be represented in the final Constitution. During the Certification Procedure, the newly appointed Constitutional Court was then charged with the task of verifying whether the final draft violated any of the Constitutional Principles.

The Certification Procedure proved to be the first judicial test for socio-economic rights under the new constitutional order. Prior to this, socio-economic rights were the subject of a political dispute and the question of their justiciability quickly became a major issue of

The Interim Constitution of 1993, supra, note 2, contained a chapter devoted to "National Unity and Reconciliation" which opened with the terms: "This Constitution provides a historic bridge between the past of a deeply divided society characterised by strife, conflict, untold suffering and injustice, and a future founded on the recognition of human rights, democracy and peaceful coexistence and development opportunities for all South Africans, irrespective of colour, race, class, belief or sex."

5 Karl Klare, Legal Culture and Transformative Constitutionalism, South African Journal of Human Rights 14 (1998), p. 150.

6

Supra, note 2 . 
debate. During the drafting of the final text, an extensive public participation programme was convened, aimed at giving ordinary citizens a say in the shaping of the Constitution. ${ }^{7}$ While many civil society organisations and most political parties campaigned for the recognition of these rights as enforceable rights, some legal scholars flatly rejected the idea. ${ }^{8}$ It was argued that these rights had no place in a constitution, first because they were political in nature and thus too vague to be the subject of adjudication, and second because they implied costly budgetary decisions over which the judiciary had no legitimate competence, according to the principle of the separation of powers. ${ }^{9}$ There was also a certain amount of concern for the stability of the Constitution, because if constitutionally enshrined rights turned out to be non-enforceable by the courts, this would have the potential to devalue the entire instrument. ${ }^{10}$

In the end, these concerns did not outweigh the fact that the struggle against apartheid and for democracy in South Africa had not simply been an appeal for civil and political rights for the African majority, but as much a call for equal opportunities and for freedom from hunger, poverty, landlessness and homelessness. ${ }^{11}$ Hence, among the general population, it was felt that the final Constitution's aspirations for social justice needed to translate into binding legal guarantees with a view to rectifying existing social and economic inequalities. As a result, the final Constitution features express constitutional rights of a socio-economic nature, the core of which can be found in sections 26 to 29 (housing, health care, food, water, social security, children's rights and education).

The political decision to include socio-economic rights as justiciable rights in the South African Constitution was subsequently approved by the Constitutional Court in its First

Sandra Liebenberg, South Africa's evolving jurisprudence on socio-economic rights, online: www.communitylawcentre.org.za/Socio-Economic-Rights/research/socio-economic-rights-jurisprudence/evolving_jurisprudence.pdf, p. 2.

8

Richard A. Epstein, Drafting a Constitution: A Friendly Warning to South Africa, American University Journal of International Law and Policy 8 (1993), p. 567-577; D. M. Davis, The Case against the Inclusion of Socio-Economic Demands in a Bill of Rights except as Directive Principles, South African Journal on Human Rights 8 (1992), p. 475-490.

9 Epstein, note 8, 568. As some authors rightly pointed out, these arguments were often driven not so much by scepticism for the constitutionalization of social rights, but rather by scepticism for constitutionalism as such; see Craig Scott/Patrick Macklem, Constitutional Ropes of Sand or Justiciable Guarantees? Social Rights in a new South African Constitution, University of Pennsylvania Law Review 141 (1992), p. 17.

10

Davis, note 8, 484.

11 Eric C. Christiansen, Adjudicating non-justiciable rights: socio-economic rights and the South African Constitutional Court, Columbia Human Rights Law Review 38 (2007), p. 328 with further references. 
Certification Judgment. ${ }^{12}$ To begin with, the Court overruled objections relating to the separation of powers. Although it conceded that the adjudication of socio-economic rights may have budgetary implications, the Court pointed out that the enforcement of civil and political rights often had such implications as well and that "it cannot be said that by including socio-economic rights within a bill of rights, a task is conferred upon the courts so different from that ordinarily conferred upon them by a bill of rights that it results in a breach of the separation of powers". ${ }^{13}$ Furthermore, the Court responded to concerns over the justiciability - or rather the supposed lack of justiciability - of the constitutional provisions on socio-economic rights, affirming that "these rights are, at least to some extent, justiciable" and that, at the very minimum, they could be "negatively protected from improper invasion". ${ }^{14}$ The Certification Procedure thus attested to the legitimate presence of socio-economic rights in the final text of the Constitution which entered into force in 1997.

\subsection{The provisions on socio-economic rights in the South African Constitution}

The South African Bill of rights is not divided into distinct chapters dealing with different types of rights, and does not label rights according to specific categories. Therefore, the first question that arises, is which rights can properly be qualified as "socio-economic rights". According to the Constitutional Court, such rights are contained in section 26, pertaining to the right to access to adequate housing, section 27 on the right to access to health care, food, water and social security, section 29 relating to the right to education, as well as section 28 which provides such rights specifically to children. ${ }^{15}$

Like most other rights in the Bill of rights, they are generally formulated in terms of "Everyone has the right to ..." before laying down specific elements for each right. Some of these specific features are framed in negative terms, such as the prohibitions on the refusal of emergency medical treatment (section 27 (3)), and on home evictions without a court order (section 26 (3)). However, these two provisions also expressly acknowledge certain positive obligations with respect to the socio-economic rights guaranteed. Subsections (2)

Ex parte Chairperson of the Constitutional Assembly: in re: Certification of the Constitution of the Republic of South Africa, 1996, Case CCT 23/96, 1996 (10) BCLR 1253, 1996 (4) SA 744

13

14

15 (CC) [hereinafter: First Certification Judgment].

Ibid., para. 77.

Ibid., para. 78 .

Ibid., para. 76; some scholars also qualify the right to a healthy environment (section 24) as a socio-economic right, cf. Pierre de Vos, Pious Wishes or Directly Enforceable Human Rights?: Social and Economic Rights in South Africa's 1996 Constitution, South African Journal on Human Rights 13 (1997), p. $71 \mathrm{f}$. 
of sections 26 and 27 each provide that "The state must take reasonable legislative and other measures, within its available resources, to achieve the progressive realisation of this right." Accordingly, these subsections create inherent limitations on the fulfillment of the positive obligations resulting from these rights: they are "qualified" by reference to reasonable measures, progressive realisation and resource constraints. ${ }^{16}$ Such qualifications are no novelty for social and economic rights, as the drafters of the Constitution clearly drew inspiration from article 2 (1) of the International Covenant on Economic, Social and Cultural Rights (ICESCR). ${ }^{17}$

Although only sections 26 and 27 contain specific language pertaining to positive obligations, this does not mean that the State's obligation to take positive measures does not extend to the other rights provided for in the Bill of rights, even if these do not explicitly require that positive measures be taken. Section 7 (2) of the Constitution states that "The state must respect, protect, promote and fulfil the rights in the Bill of rights." and thus establishes positive as much as negative obligations for every right guaranteed, irrespective of the category of rights to which it is attributed. Insofar, the Constitution once more borrowed from international human rights law by incorporating the concept of "respect, protect, fulfill", 18 as employed by the United Nations treaty bodies. ${ }^{19}$

Finally, the Bill of rights provides for a general limitation clause in section 36, which applies indiscriminately to all rights guaranteed and according to which "The rights in the Bill of rights may be limited only in terms of law of general application to the extent that the limitation is reasonable and justifiable in an open and democratic society based on

Liebenberg, note 7, p. 5; Fons Coomans, Reviewing Implementation of Social and Economic Rights: An Assessment of the "Reasonableness" Test as Developed by the South African Constitutional Court, Zeitschrift für ausländisches öffentliches Recht und Völkerrecht 65 (2005), p.170; however, Coomans considers the rights as such to be qualified whereas it is in fact only the positive dimension of these rights that is subject to the said qualifications, see Jaftha $v$ Schoeman and Van Rooyen v Stoltz, Case CCT 74/03, 2005 (2) SA 140 (CC), 2005 (1) BCLR 78 (CC) [hereinafter: Jaftha], para. 31.

International Covenant on Economic, Social and Cultural Rights of 16 December 1966, 993 U.N.T.S. 3 [hereinafter: ICESCR]. Article 2 (1) reads: "Each State Party to the present Covenant undertakes to take steps, individually and through international assistance and co-operation, especially economic and technical, to the maximum of its available resources, with a view to achieving progressively the full realization of the rights recognized in the present Covenant by all appropriate means, including particularly the adoption of legislative measures." Inexplicably, the ICESCR remains the only major human rights treaty that South Africa has failed to ratify until this day; cf. Liebenberg, note 7, p. 2.

The concept was originally developed by Asbjфrn Eide, Realization of Social and Economic Rights and the Minimum Threshold Approach, Human Rights Law Journal 10 (1989), p. 37.

19

See, for example, Committee on Economic, Social and Cultural Rights, General Comment No. 19, The right to social security (art. 9), 4 February 2008, U.N. Doc. E/C.12/GC/19, para. 43ff. 
human dignity, equality and freedom". Since the positive obligations under sections 26 and 27 are subject to specific qualifications, section 36 will normally be invoked only in the context of the negative dimension of the rights in question. ${ }^{20}$

All elements considered, the Constitution provides a general framework for socioeconomic rights that is formulated entirely in abstract terms and which does not clarify the content of these rights. For example, whether the term "adequate housing" signifies anything more than shelter, in the form of a roof over one's head, can in no way be derived from the wording of section 26. Likewise, the Constitution does not define what should be considered a "reasonable measure" within the sense of subsections 26 (2) and 27 (2). It has thus been left to the courts to explore the reasoning of these broad provisions and to specify their meaning through constitutional interpretation. What has ensued from this exercise is a body of jurisprudence that is unparalleled in both its ambition and its accomplishments.

\section{The judicial protection of socio-economic rights in South Africa}

Since 1997, the case law on socio-economic rights in the South African Constitution has continuously gathered momentum and has attracted considerable attention even beyond the country's borders. While the number of cases dealing with these rights grows steadily, the three judgments of the Constitutional Court which will be analyzed in this section are considered to be the leading cases on socio-economic rights. These cases - Soobramoney, Grootboom and Treatment Action Campaign - may be characterized as a "landmark trilogy" which displays a distinctive narrative that draws a timeline from the infancy to the early adulthood of socio-economic rights jurisprudence, the latter phase being characterised by a discernible methodological maturity in the adjudication of these rights.

\subsection{The trilogy of landmark cases}

3.1.1. Soobramoney v Minister of Health (KwaZulu-Natal) ${ }^{21}$

The very first case concerning socio-economic rights to come before the Constitutional Court, in 1997, dealt with the right to have access to health care (section 27$)^{22}$. The appel-

"1. Everyone has the right to have access to-

a. health care services, including reproductive health care;

b. sufficient food and water; and 
lant, Mr. Soobramoney, was an unemployed man with chronic kidney failure who was in need of regular, life-prolonging dialysis treatment. The state hospital in Durban denied him treatment because of scarce resources which, according to the hospital's guidelines, were to be used to treat patients waiting for kidney transplants. Mr. Soobramoney also suffered from heart disease and cerebro-vascular disease, and was thus not eligible for a transplant, which precluded him from receiving dialysis treatment. In his appeal to the Constitutional Court, he asked for the hospital to be ordered to provide the treatment to extend his life, relying mainly on section 27 (3) which states that "[n]o one may be refused emergency medical treatment."

The Court dismissed this argument, holding that the appellant's chronic condition did not constitute an "emergency" in the sense of section 27 (3) but an ongoing state of affairs due to an incurable condition. ${ }^{23}$ Although the appellant's submission did not address the question, the Court went on to probe whether section 27 (1), pertaining to the right to have access to health care services, could provide a basis for his claim. However, given the large margin of discretion granted to the state for the setting of budgetary priorities, the Court found that the hospital was justified in drawing up guidelines for determining which patients would get treatment, asserting that "[a] court will be slow to interfere with rational decisions taken in good faith by the political organs and medical authorities whose responsibility it is to deal with such matters." 24 Consequently, the Court declined to order the remedy sought by Mr. Soobramoney.

There can be no doubt that high expectations weighed heavily on the shoulders of the Constitutional Court when it rendered its first judgment relating to socio-economic rights, and for the most part, these expectations were not met. While there was little to disagree about in the result of the judgment, that is, the refusal to order the provision of treatment, ${ }^{25}$ much criticism has been aimed at the Court's reasoning and the language it employed. For instance, the Court's willingness to defer to the political level of decision-making seemed to be in opposition not only to the Constitution's commitment to judicially enforceable

c. social security, including, if they are unable to support themselves and their dependents, appropriate social assistance.

2. The state must take reasonable legislative and other measures, within its available resources, to achieve the progressive realisation of each of these rights.

3. No one may be refused emergency medical treatment."

Ibid., para. 21.

Ibid., para. 29.

Craig Scott/Philip Alston, Adjudicating Constitutional Priorities in a Transnational Context: A Comment on Soobramoney's Legacy and Grootboom's Promise, South African Journal on Human Rights 16 (2000), p. 252. 
rights, ${ }^{26}$ but also to the Court's proper analysis in the First Certification Judgment, where it was argued that budgetary decisions could legitimately be taken by courts whenever the adjudication of rights so required ${ }^{27}$. As a result of this deference, the Court abstained from determining the extent of resources available to the state. Instead, the ruling suggested that "available resources" were whatever resources the state asserted to be available to it. ${ }^{28}$ Moreover, the Court was wary of the task of weighing specific socio-economic shortcomings against the constitutional standard of socio-economic rights, arguing instead that in the light of the multitude of problems to address, a "holistic approach to the larger needs of society" was preferable to focussing "on the specific needs of particular individuals". 29 The central motive behind this approach was revealed in the concurring opinion of Madala $\mathrm{J}$ : "Some rights in the Constitution are the ideal and something to be strived for. They amount to a promise, in some cases, and an indication of what a democratic society aiming to salvage lost dignity, freedom and equality should embark upon."30 This language suggests that the Court was unable to distance itself from the classic preconception of a dichotomy between the two categories of human rights, that is, civil and political rights on the one hand and economic, social and cultural rights on the other. As a consequence, it conceived socio-economic rights as directive principles rather than as what the Constitution intended them to be, namely justiciable rights. ${ }^{31}$

In sum, numerous questions remained unresolved after Soobramoney. The Court's deferential approach gave rise to the concern that socio-economic rights were not taken seriously and the fact that the appellant died within days of learning about the results of the ruling only exacerbated this concern. ${ }^{32}$

Marcus Pieterse, Coming to Terms with Judicial Enforcement of Socio-Economic Rights, South African Journal on Human Rights 20 (2004), p. 402; Jeanne M. Woods, Justiciable Social Rights as a Critique of the Liberal Paradigm, Texas International Law Journal 38 (2003), p. 782.

Supra, note 13; see the critique by Darrel Moellendorf, Reasoning about Resources: Soobramoney and the Future of Socio-Economic Rights Claims, African Journal on Human Rights 14 (1998), p. 331.

Charles Ngwena, Adjudicating socio-economic rights - Transforming South African society?: A response to Linda Jansen van Rensburg's paper, Potchefstroom Electronic Law Journal 6 (2002), p. 3, online: http://ajol.info/index.php/pelj; Christiansen, note 11, p. 362, however, sees this differently, submitting that the Court had, in fact, reviewed "the actual evidence of the financial status of the hospital", but this assertion is not corroborated by the judgment itself.

30 Soobramoney, note 21, para. 31 .

30 Ibid., para. 42.

31 Ngwena, note 28 , p. 4

32

Christiansen, note 11, p. 364 . 


\subsubsection{Government of the Republic of South Africa v Grootboom ${ }^{33}$}

Three years after Soobramoney, the Constitutional Court was again called to decide a case on socio-economic rights, this time involving the right to access to adequate housing as provided for by section 26 of the Constitution. ${ }^{34}$ The case is named after Irene Grootboom, who was part of a group of 900 squatters (which included 390 adults and 510 children), who had decided to unlawfully occupy a piece of private land after leaving an informal settlement due to intolerable hygiene conditions and were waiting to be allocated low-cost housing. The owner of the land pursued their eviction, following which the group camped out in a sports field under plastic sheeting. Consequently, an urgent application for an order requiring the government to provide them with "adequate basic temporary shelter or housing" was filed on their behalf before the Cape of Good Hope High Court. ${ }^{35}$ Their complaint relied upon section 26 (1) and - as far as the children in the group were concerned - upon section 28 (1)(c), which states that "Every child has the right- c) to basic nutrition, shelter, basic health care services and social services". It proved to be successful at least insofar as the High Court ordered the government to provide shelter for the children, and the parents accompanying them. ${ }^{36}$ The Constitutional Court, however, reached quite a different conclusion and dismissed the claim under section 28. It based its reasoning solely on section 26, and concluded that the government's housing programme "fell short of the obligations imposed upon the state by section 26 (2) in that it failed to provide for any form of relief to those desperately in need of access to housing",37. Yet, despite the unconstitutionality of the housing programme, the squatters were not entitled to claim shelter immediately upon demand. Rather, the government was ordered "to devise and implement within its available

Government of the Republic of South Africa and others v Irene Grootboom and others, Case CCT 11/00, 2001 (1) SA 46 (CC) [hereinafter: Grootboom].

Section 26 provides:

"1. Everyone has the right to have access to adequate housing.

2. The state must take reasonable legislative and other measures, within its available resources, to achieve the progressive realisation of this right.

3. No one may be evicted from their home, or have their home demolished, without an order of court made after considering all the relevant circumstances. No legislation may permit arbitrary evictions."

Ibid., para. 13.

36

Ibid., para. 16; for a summary of the High Court judgment, see Karrisha Pillay/Sandra Liebenberg, Grootboom v Oostenberg Municipality and Others Economic and Social Rights Review 2 (No. 3) (2000), p. 17. 
resources a comprehensive and coordinated programme progressively to realise the right of access to adequate housing". 38

The Constitutional Court's judgment in Grootboom is noteworthy in several respects. The Court took an outright approach to the question of whether socio-economic rights were justiciable. Recalling the observations about justiciability in the First Certification Judgment, the Court explained that "[t]he question is therefore not whether socio-economic rights are justiciable under our Constitution, but how to enforce them in a given case." 39 This standpoint set the stage for an interpretative analysis of the right to access to adequate housing and its inherent qualifications relating to reasonable measures, available resources and progressive realisation. The Court somewhat conflated these three elements into a single methodological test for the fulfillment of the state's positive obligations, the socalled "test of reasonableness". ${ }^{40}$ Based on this test, the Court examined whether the measures taken by the state in relation to the situation of the squatters, notably the state's housing programme, lived up to the constitutional requirements, which were detailed as follows: first, in order to pass the "test of reasonableness", a programme must be comprehensive, coherent, coordinated and capable of facilitating the realisation of the right; second, it also has to be balanced and flexible and appropriate for short-, medium- and long-term needs. Third, a reasonable programme must clearly allocate responsibilities and tasks to the different spheres of government and ensure that financial and human resources are available. Fourth, it must be reasonably formulated and implemented and it must provide for the needs of those most desperate by providing relief for people who are living in intolerable or crisis situations. ${ }^{41}$ It was this last criterion which the state's housing programme failed to fulfill because it left out of account "the immediate amelioration of the circumstances of those in crisis" 42 and thus did not show that the state was meeting the positive obligations imposed on it by section 26 (2). As a result, the government was ordered to revise its housing programme, ${ }^{43}$ however no order was issued to directly provide the plaintiffs with relief.

Ibid., para. 99.

Ibid., para. 20.

40 Ibid., para. 44; see also Christiansen, note 11, p. 366 on the fact that the Court somewhat abandoned the availability of resources and the progressiveness as separate legal requirements of section 26 (2). At para. 46 of the judgment, the Court explicitly explained that "the availability of resources is an important factor in determining what is reasonable."

Grootboom, note 33, paras. 40-44.

42

Ibid., para. 64.

43

However, no specific time frame within which the state had to act was imposed with the result that little visible changed was achieved, see Dennis Davis, Socio-economic rights in South Africa, 
In many ways, the Grootboom judgment managed to make up for the shortcomings of Soobramoney. Instead of watering down the right to have access to housing to a general aspiration to be strived for, the Court took this right for what it is: a constitutional right to be enforced by the courts. ${ }^{44}$ As a consequence of this change in mindset, the Court's reasoning in Grootboom was clearly concerned with methodological considerations and went beyond the application of section 26 to the case at hand by developing an analytical framework for the adjudication of socio-economic rights. Grootboom thus became the leading precedent for all subsequent claims based on the socio-economic rights provided for in the Constitution.

\subsection{Minister of Health $v$ Treatment Action Campaign ${ }^{45}$}

Completing the "landmark-trilogy" was a case initiated by the advocacy group Treatment Action Campaign, among other organisations, often referred to as the Nevirapine case. It concerned the government's policies with respect to HIV/AIDS, more specifically those relating to mother-to-child-transmission of HIV at birth. The programme that was being challenged regulated the administration of the anti-retroviral drug Nevirapine, which is known to prevent the transmission of the virus during birth through a single dosage and which had been made available to the government by the manufacturer free of charge for a period of five years. The government had decided to limit access to the drug to a number of research and training sites, thus effectively blocking the coverage of $90 \%$ of all affected births nation-wide. Before the Constitutional Court, Treatment Action Campaign argued that this programme violated section 27 (1)(a) of the Constitution, ${ }^{46}$ the right to have access to health care services, including reproductive health. The case succeeded on all accounts, and the orders sought by the applicants were granted substantially in the terms sought. ${ }^{47}$ Drawing on its judgment in Grootboom, the Constitutional Court relied on the "test of reasonableness" to decide that the programme which restricted the use of Nevirapine to the pilot sites, as well as the absence of a comprehensive and coordinated programme to combat mother-to-child-transmission, constituted breaches of the state's obligations under

The record of the Constitutional Court after ten years, Economic and Social Rights Review 5 (No. 5) (2004), p. 5.

Ngwena, note 28, p. 6.

45

Minister of Health and Others v Treatment Action Campaign and Others, Case CCT 8/02, 2002

(10) BCLR 1033 (CC) [hereinafter: Treatment Action Campaign or TAC]; for a summary of the judgment, see Sibonile Khoza, Reducing mother-to-child transmission of HIV: The Nevirapine case, Economic and Social Rights Review 3 (No. 2) (2002), p. 2.

47

Supra, note 22.

Liebenberg, note 7, p. 22. 
section 27 (2). As a result, government was ordered to remove the restrictions and to devise and implement a more adequate programme to tackle the issue. ${ }^{48}$

The judgment in Treatment Action Campaign marked the end of all judicial debates about the justiciability of the socio-economic rights under the South African Constitution. The Constitutional Court in fact set off its reasoning with an unequivocal observation in this regard: "The question in the present case, therefore, is not whether socio-economic rights are justiciable. Clearly they are. ${ }^{, 49}$ Having once and for all removed this traditional stumbling block for the adjudication of claims based on socio-economic rights, the Court devoted the core of its judgment to the examination of the criteria of "reasonableness" as laid out in Grootboom. It found that there was no justification for withholding a potentially life-saving drug from those who relied on the public health care system, most often due to poverty ${ }^{50}$. Furthermore, given the fact that the entire governmental strategy with respect to mother-to-child-transmission of HIV was intricately linked to the conduct of research at the pilot sites, the Court could not help but conclude that the programme as a whole failed the "test of reasonableness" and had to be replaced with one that was in conformity with the state's obligations under the right of access to health care. ${ }^{51}$

Although it was only the third judgment the Constitutional Court had handed down in the field of socio-economic rights, Treatment Action Campaign also marked the beginning of a profound doctrinal debate about an appropriate methodology for adjudicating socioeconomic rights. While the Court was consistent in its application of the "test of reasonableness", it did not significantly advance the methodology employed in Grootboom. This did not go unnoticed amongst scholars and many have criticised the Court's reasoning on the basis of this lack of innovation. ${ }^{52}$ The following section will outline the main achievements of the South African jurisprudence on socio-economic rights as well as take up some of the criticism - and the constructive proposals - that have emerged from these cases.

51

52

Treatment Action Campaign, note 45, para. 135.

Ibid., para. 25. It would appear that the issue of justiciability of socio-economic rights was never again raised in the judgments of the Constitutional Court.

Ibid., para. 80 .

Ibid., para. 95.

See, for example, David Bilchitz, Placing basic needs at the centre of socio-economic rights jurisprudence, Economic and Social Rights Review 4 (No. 1) (2003), p. 2; Mark Heywood, Contempt or compliance? The TAC case after the Constitutional Court judgment, Economic and Social Rights Review 4 (No. 1) (2003), p. 7. 


\subsection{Achievements and drawbacks of the South African case-law on socio-economic rights}

Ever since the Constitutional Court's judgment in Treatment Action Campaign, the South African jurisprudence on socio-economic rights has moved from novelty to normality. Subsequent cases in this field have not generated nearly as much attention as the three landmark cases presented above and the more recent judgments by the Constitutional Court have not substantially altered the methodological approach to socio-economic rights. The "test of reasonableness" in particular has remained unchanged. Some methodological issues not previously addressed in Grootboom and Treatment Action Campaign and unrelated to the "test of reasonableness" did, however, present themselves, such as the question of equality in the context of socio-economic rights ${ }^{53}$ and the limitation of the negative obligations resulting from these rights. ${ }^{54}$ The right to have access to adequate housing has been at the center of the later case law, ${ }^{55}$ with general considerations about the nature and meaning of socio-economic rights having become increasingly rare.

This may soon change, however, as a highly publicised case concerning the right to have access to water - commonly referred to as the Phiri water case - is currently before the Constitutional Court. ${ }^{56}$ The judgment in this matter is eagerly awaited amongst scholars and activists because it presents an opportunity to further develop the framework for socioeconomic rights. The case concerns the question of whether the state has a duty to provide free water to its citizens and whether the instalment of pre-paid water meters is a measure that is in conformity with the Constitution's guarantees. Not only has the Constitutional Court never pronounced itself on the right to water, the Supreme Court of Appeal's judg-

Khosa and Others $v$ The Minister of Social Development and Others, Case CCT 12/03, 2004 (6) BCLR 569 (CC).

54

55

President of the Republic of South Africa and Others $v$ Modderklip Boerdery (Pty) Ltd and Others, Case CCT 20/04, 2005 (5) SA 3 (CC), 2005 (8) BCLR 786 (CC); Port Elizabeth Municipality v Various Occupiers, Case CCT 53/03, 2005 (1) SA 217 (CC), 2004 (12) BCLR 1268 (CC); Occupiers of 51 Olivia Road Berea Township and 197 Main Street Johannesburg $v$ City of Johannesburg and Others, Case CCT 24/07, 2008 (3) SA 208 (CC), 2008 (5) BCLR 475 (CC), [2008] ZACC 1.

56

The case is registered as Mazibuko and Others v City of Johannesburg and Others, Case CCT 39/09. The appeal against the judgment of the Supreme Court of Appeal - City of Johannesburg $v$ L Mazibuko (489/08) [2009] ZASCA 20 [hereinafter: Mazibuko] - was heard by the Constitutional Court on 2 and 3 September 2009. For a case review of the judgment of the Supreme Court of Appeal, see Jackie Dugard/Sandra Liebenberg, Muddying the waters, The Supreme Court of Appeal's judgment in the Mazibuko case, Economic and Social Rights Review 10 (No. 2) (2009), p. 11. 
ment in the matter also indicates that the highest court will have to address some fundamental questions relating to the progressiveness of socio-economic rights and to the appropriate margin of discretion granted to the authorities when allocating fundamental goods and services.

The current state of the case law and its future relevance for cases such as the Phiri water case invites the question whether the development of the socio-economic rights jurisprudence has taken the right direction. Amongst the many aspects that could be dealt with in this respect, the following discussion will elaborate on three in particular: (a) the merits and the pitfalls of the "test of reasonableness", (b) the coherence between the South African approach to socio-economic rights and the conception under international law, and (c) the impulse this case law has given to comparative analyses in the field of constitutionally enshrined socio-economic rights.

\subsubsection{The test of reasonableness}

While having become a recurrent element in socio-economic rights jurisprudence, the "test of reasonableness" is still a rather recent concept. As Liebenberg notes, the application of the doctrine of separation of powers and the extent to which the courts are willing to intervene in socio-economic policy matters remains a highly contested terrain. ${ }^{57}$ Reasonableness review has not fulfilled the herculean task of drawing a clear-cut line between these competing interests. However, it does touch upon both of them, because it not only operates as a standard of scrutiny for the courts to assess governmental conduct, but also as a standard for the government to conduct policy and draft legislation ${ }^{58}$. In this sense, the Constitutional Court has created a flexible tool for the adjudication of claims based on socio-economic rights, which allows the government to frame its legislation according to the criteria set out by the Court. Some of the test's elements come close to threshold requirements, most notably the obligation to cater to those whose needs are most urgent, which played a role in both Grootboom and Treatment Action Campaign ${ }^{59}$.

The positive and negative obligations under the socio-economic rights provisions of the Constitution, notably under sections 26 and 27, are subject to different types of limitations. Judicial review of the negative obligations does not rely on the "test of reasonableness", but

59 Sandra Liebenberg, Basic rights claims, How responsive is 'reasonableness review'?, Economic and Social Rights Review 5 (No. 5) (2004), p. 9. 
on the Constitution's general limitations clause (section 36). ${ }^{60}$ However, it may be argued, that the fundamental principles lying at the heart of the "test of reasonableness" correspond with the notions that form the basis for the general limitations clause. Just like the general limitations clause, the "test of reasonableness" endorses the idea of government having to justify its policy choices. Also, it is designed to be sensitive to the historical and social context in South Africa and places great importance on taking into account the inherent dignity of all human beings in the evaluation of the reasonableness of state action. As the Court put it in Grootboom, "[t]he Constitution will be worth infinitely less than its paper if the reasonableness of state action concerned with housing is determined without regard to the fundamental constitutional value of human dignity. [...] [H] uman beings are required to be treated as human beings." "61 In a more general sense, it may be said that the different elements which make up the "test of reasonableness" overall, are all inspired by fundamental constitutional values, such as human dignity, good governance or social justice. The criterion of reasonableness is therefore not an autonomous concept. "Reasonable" more precisely means "constitutionally reasonable" or "reasonable in the light of the Constitution", which makes it a legitimate standard for reviewing the actions of a state that is, in any case, bound by such constitutional values. In sum, it can be said that the "test of reasonableness" is in fact a variation of the general limitations clause, namely one that is adapted to the review of positive obligations.

However, the success of the "test of reasonableness" in rendering socio-economic rights enforceable has also been one of the weaknesses of this jurisprudence, in some respects. As some authors have noted, the Court's fixation on reasonableness review has had an adverse effect on the determination of the content of the rights in question. ${ }^{62}$ While Grootboom did contain some insights about what constitutes "adequate housing" in the sense of section 26

Supra, note 20 and corresponding text.

Section 36 (1) provides:

"The rights in the Bill of Rights may be limited only in terms of law of general application to the extent that the limitation is reasonable and justifiable in an open and democratic society based on human dignity, equality and freedom, taking into account all relevant factors, including-
a. the nature of the right;
b. the importance of the purpose of the limitation;
c. the nature and extent of the limitation;
d. the relation between the limitation and its purpose; and
e. less restrictive means to achieve the purpose."

61 Grootboom, note 33, para. 83.

62

David Bilchitz, Placing basic needs at the centre of socio-economic rights jurisprudence, Economic and Social Rights Review 4 (No. 1) (2003), p. 2. 
of the Constitution, ${ }^{63}$ the Court's judgment in Treatment Action Campaign completely omitted this initial step of defining the specific interests protected by the right to access to health care services. Such criticism had previously been aimed at the Court's reasoning in Soobramoney, ${ }^{64}$ where the substance of the right to health care services was not examined, albeit for different reasons than in Treatment Action Campaign. The problem with the lack of interpretation of the rights concerned is the fact that it tends to misconstrue the meaning and purpose of socio-economic rights. Their primary purpose is not to identify insufficiencies in the justification of state measures. What is relevant for the adjudication of these rights in general, are those measures that touch upon fundamental individual interests. Yet, a governmental programme can be unreasonable without necessarily interfering with the constitutionally enshrined rights of individuals. The sole focus on reasonableness review tends to translate into an objective type of standard that is not supposed to be at the centre of rights adjudication. It may be argued that Treatment Action Campaign was not a case which necessitated lengthy considerations about the meaning and content of the right to access to health care services, since tolerating that newborns be infected with a deadly virus constituted such a flagrant breach of this right. However, a short clarifying remark by the Court in this regard could have offered some useful orientation for future cases.

\subsubsection{The South African case law in the light of international human rights law}

One of the particularities of the South African Constitution is its relationship to international law. Several provisions explicitly address the role that international law is to play in the interpretation of the Constitution. Among the general provisions set out in chapter 14, an entire sub-title "International Law" consisting of three sections addresses the binding force of international agreements and customary international law as well as their domestic application. Section 233 provides that a tribunal must always give preference to an interpretation of the law which is consistent with international law. In addition, the Bill of rights provides for a distinct provision on the consideration of international law in the interpretation of the rights guaranteed. Section 39 states that, when interpreting the Bill of rights, courts must consider international law. ${ }^{65}$ This includes binding as much as non-binding

63

See Grootboom, note 33, para. 35 in which the Court declares that adequate housing "requires available land, appropriate services such as the provision of water and the removal of sewage and the financing of all of these, including the building of the house itself."

64

65
"When interpreting the Bill of Rights, a court, tribunal or forum-

a. must promote the values that underlie an open and democratic society based on human dignity, equality and freedom; 
international law. ${ }^{66}$ The Constitution itself thus creates an interconnectedness between the Bill of Rights and international human rights law, which is certainly due to the fact that most of its provisions on substantive rights are clearly inspired by international conventions in this field. The socio-economic rights in the Constitution are no exception in this respect. $^{67}$

Against this framework, it is somewhat surprising that the Constitutional Court's methodology for socio-economic rights falls short of the international parameters for dealing with economic, social and cultural rights. In Grootboom, the Court duly fulfilled its task of consulting the relevant international norms, most notably the ICESCR and its interpretation by the competent treaty monitoring body, the Committee on Economic, Social and Cultural Rights. ${ }^{68}$ Nevertheless, it clearly and explicitly departed from one of the key concepts advanced under international law, namely the so-called "minimum core obligations". According to the Committee, the ICESCR obliges states to ensure the satisfaction of minimum essential levels of each of the rights, prima facie without regard to resource constraints. ${ }^{69}$ In both Grootboom and Treatment Action Campaign it was argued that the same approach should be adopted in the context of sections 26 (2) and 27 (2) of the South African Constitution, given their resemblance with art. 2 (1) of the ICESCR. The Court however refused to embrace this concept, claiming at first that it did not have sufficient information to determine what would comprise the minimum core obligation in the context of the Constitution ${ }^{70}$ and later indicating that it was impossible to give everyone access to a core service immediately. ${ }^{71}$ There was also a certain measure of deference involved in the Court's stance, as evidenced by its assertion that "the courts are not institutionally equipped to make the wide-ranging factual and political enquiries necessary for determining what the minimum-core standards [...] should be."72 The "minimum core" thus became one factor

b. must consider international law; and

c. may consider foreign law."

$S v$ Makwanyane and Another, Case CCT 3/94, 1995 (3) SA 391 (CC), 1995 (4) BCLR 665 (CC), para. 35.

Supra, p. 553.

Grootboom, note 33, paras 26ff.

Committee on Economic, Social and Cultural Rights, General Comment 3, The nature of States parties obligations (Art. 2, par.1), contained in UN Doc. E/1991/23, para 10.

Grootboom, note 33, para. 33.

Treatment Action Campaign, note 45, para. 35.

Ibid., para. 37. 
amongst many in deciding whether a certain state measure or set of measures could satisfy the "test of reasonableness". 73

The Court's decision to reject the "minimum core" approach was met with criticism. It was contended that this decision had led to a situation where no clear guidance was given to the government as to the obligations that should be given priority under the socio-economic rights provisions. ${ }^{74}$ However, offense was primarily taken at the blanket observation that providing citizens with minimum essential levels of basic socio-economic goods and services went beyond the powers of the state. While this may have been true in the light of South Africa's social and economic development at the time and perhaps even today, the statement was not supported by any kind of proof that the government did in fact lack this capacity. ${ }^{75}$ Rather than saying, that from a legal point of view, it was not desirable to construe socio-economic rights as possessing an absolute core that would entitle claimants to seek immediate relief, the Court brushed this idea off as unrealistic, and almost naïve. By doing so, it relieved the state of a considerable part of its burden to show that it had done everything in its power to ensure that the population's most urgent needs were met. As a way of remedying this weakness, Liebenberg proposes to tighten the justificatory elements of the reasonableness test by requiring the state to show that its resources are inadequate for meeting basic human needs in the light of other compelling government purposes. ${ }^{76}$

By rejecting the "minimum core" approach, the Constitutional Court dismissed the idea that socio-economic rights can have a definite content that is not subject to progressiveness and resource constraints. As a consequence, the socio-economic rights jurisprudence is certainly not as robust as it could be and as many scholars would wish for it to be. There are nevertheless some lessons to be drawn in the rejection of the "minimum core" at the national level. Before the South African jurisprudence developed, the only viable methodological approach to socio-economic rights was the one advanced by the Committee on Economic, Social and Cultural Rights. However, this Committee is concerned with the interpretation of an international treaty. Although the socio-economic rights in the South African Constitution may bear a striking resemblance to the provisions of the ICESCR, they do not operate in the same legal sphere. As Coomans notes, unlike the South African Constitutional Court, the Committee is not part of a system of separation of powers, and consequently does not have to show deference to another branch of government when 
assessing a state's performance. ${ }^{77}$ State reporting procedures are weak when compared to any form of judicial rights protection, but particularly to constitutional rights protection. It remains to be seen whether the Committee will stand by its "minimum core" approach when it will eventually assume its quasi-judicial competence to hear individual complaints about the violation of the rights in the ICESCR. ${ }^{78}$

Another difference between the Committee and the Constitutional Court is the fact that the state reporting procedure is not concerned with crafting out remedies for the violations the Committee finds to exist in a given state. While it may make particular suggestions and recommendations to the state parties, the Committee is not in a position to order the state to take specific action. However, in the case of the Constitutional Court, finding a breach of the Constitution generally entails granting appropriate relief. ${ }^{79}$ The Court is thus expected to remedy the violation and to formulate a court order which will specify the measures to be taken by government. By rejecting the concept of "minimum core obligations", the Court arguably avoided difficult decisions of a political and budgetary nature in trying to find an appropriate remedy. 80

It should be noted that the Phiri water case may require the Constitutional Court to reconsider its stand on the "minimum core" approach since the case inevitably involves the question of what constitutes sufficient water in terms of section 27 (1) of the Constitution. Although the Supreme Court of Appeal did not explicitly invoke the concept of "minimum core", its reasoning is clearly based on the assumption of the right to a minimum essential level of water: "A commitment to address a lack of access to clean water and to transform our society into one in which there will be human dignity and equality, lying at the heart of our Constitution, it follows that a right of access to sufficient water cannot be anything less than a right of access to that quantity of water that is required for dignified human exis-

77

78

The Optional Protocol to the International Covenant on Economic, Social and Cultural Rights providing for this competence was adopted by the United Nations General Assembly on 10 December 2008. It opened for signature on 24 September 2009 and will enter into force upon ratification by ten states.

79

80

Section 38 of the final Constitution reads as follows: "Anyone listed in this section has the right to approach a competent court, alleging that a right in the Bill of Rights has been infringed or threatened, and the court may grant appropriate relief, including a declaration of rights. [...]" According to section 172 (1), "When deciding a constitutional matter within its power, a court [...] may make any order that is just and equitable."

Christiansen, note 11, p. 384. 
tence." 81 It will be interesting to see how the Constitutional Court will handle this issue and whether it will continue to distance itself from the international concept of "minimum core".

Yet, even if this disparity should persist, there can be little doubt that the South African jurisprudence on socio-economic rights has significantly advanced the cause of economic, social and cultural rights at the international level. ${ }^{82}$ While for many years, scholars and human rights institutions had argued in favour of the justiciability of economic and social rights, this jurisprudence delivered a first-hand experience of what justiciability meant in practice. It single-handedly replaced the question of "whether" economic, social and cultural rights could be justiciable with that of "how" they could be justiciable. The fact that the Constitutional Court answered this question by relying heavily on concepts that were developed at the international level, is proof that the long-time international endeavours to realize economic, social and cultural rights bore fruit. Finally, it is probably safe to say that the South African jurisprudence had a positive influence on the process that led to the adoption of the Optional Protocol to the International Covenant on Economic, Social and Cultural Rights, which provides for an individual complaints procedure. ${ }^{83}$

\subsubsection{The South African jurisprudence and comparative constitutional law}

Another field in which the South African jurisprudence on socio-economic rights has had a lasting impact is the field of comparative constitutional law, more precisely comparative rights jurisprudence. The innovative force of the Constitutional Court's case law did not go unnoticed in other constitutional systems around the world.

The South African Constitution itself encourages comparisons with other Constitutions because it invites the courts to consider foreign law when interpreting the Bill of rights ${ }^{84}$. While having regard to foreign law is an optional exercise, the courts are in no way limited to considering "comparable" foreign law. ${ }^{85}$ Any foreign legal system may thus be consulted and the Constitutional Court makes extensive use of this possibility in its judgments. ${ }^{86}$

Mazibuko, note 56, para. 17; the Supreme Court of Appeal ruled that a minimum of 42 litres of water per resident per day would constitute sufficient water in terms of section 27(1) of the Constitution, ibid., para. 62.

Liebenberg, note 59, p. 7.

83

84

85

86

Supra, note 78 .

Supra, note 65.

The Interim Constitution did in fact contain a limitation to comparable foreign law in its interpretative provision (section 35 (1)).

See, for example, the Makwanyane judgment, supra, note 66 , on the unconstitutionality of the death penalty. 
However, in the field of socio-economic rights, little foreign jurisprudence is available. The legal systems which the Court has preferred to consult in other contexts, such as the United States, Canadian and German Constitution, ${ }^{87}$ are mute on socio-economic rights. In Soobramoney, the Court had recourse to the case law of the Supreme Court of India concerning the positive obligations imposed on the state with respect to the right to life. ${ }^{88}$

The openness towards comparative rights analysis that transpires from the South African Constitution and jurisprudence may have served as a source of inspiration to foreign scholars. While the novelty of justiciable socio-economic rights would presumably have been in and of itself enough to attract the attention of those who had previously argued for the inclusion of this type of rights in their own constitutional order, the fact that the South African Constitutional Court explicitly pursued interpretative avenues based on international and comparative sources certainly added to its appeal. As a result, a number of authors have explored the methodological potential and the possibilities for reform which this jurisprudence presents for other constitutional systems. ${ }^{89}$

In many jurisdictions, the subject of socio-economic rights had, up until recently, solely been debated in terms of whether or not these rights were justiciable. ${ }^{90}$ The debate has traditionally stalled at this point due to a lack of proof for either of the opposing arguments. The South African jurisprudence has changed this and recent publications dealing with justiciability attest to this. ${ }^{91}$ In fact, many of the theoretical arguments brought forward against the justiciability of socio-economic rights can now be verified based on actual judicial experience. First, the assertion that the adjudication of socio-economic rights

See the Court's comparative analysis on the question of remedies in Treatment Action Campaign, note 45 , para. $107 \mathrm{ff}$.

Soobramoney, note 21, para. 15ff.

89

Malcolm Langford (ed.), Social Rights Jurisprudence, Emerging Trends in International and Comparative Law, Cambridge 2008; Mark Tushnet, Weak courts, strong rights: judicial review and social welfare rights in comparative constitutional law, Princeton and Oxford 2008, p. 227ff.; Margit Tveiten, Justiciability of socio-economic rights: Reflections on Norwegian and South African debate and experience, in: Wenche Barth Eide / Uwe Kracht (eds.), Food and Human Rights in development, Volume I Legal and institutional dimensions and selected topics, Antwerpen 2005, p. 163; Mirja Trilsch, Die Justiziabilität wirtschaftlicher, sozialer und kultureller Menschenrechte im innerstaatlichen Recht, forthcoming.

For an overview of the arguments, see Aoife Nolan/Bruce Porter/Malcolm Langford, The Justiciability of Social and Economic Rights: An Updated Appraisal, Paper prepared for the Human Rights Consortium, Belfast, Northern Ireland, August 2007, online: http://ssrn.com/abstract= 1434944; Christoph Gusy, Les droits sociaux sont-ils nécessairement injusticiables?, in: Constance Grewe / Florence Benoît-Rohmer (eds.), Les droits sociaux ou la démolition de quelques poncifs, Strasbourg 2003, p. 33. 
would prove to be an inappropriate and unmanageable role for the courts has turned out to be unfounded $^{92}$. The South African Constitutional Court has demonstrated that it is quite capable of dealing with the implications of adjudicating socio-economic claims in a coherent and nuanced manner. Second, it was predicted that the Constitution would be discredited in the eyes of the public, since the courts would be unwilling and unable to enforce socio-economic rights. However, the opposite was shown to be the case. The jurisprudence that is continuing to develop has had a tangible impact on some of the most disadvantaged groups in society. ${ }^{93}$ Finally, the South African cases also illustrate that socioeconomic claims do not require courts to take resource-allocational decisions. As the Constitutional Court put it in Treatment Action Campaign, its judicial review in the form of the "test of reasonableness" "may in fact have budgetary implications" but is not "directed at rearranging budgets" $"$. So while the Court will neither directly interrogate, nor prescribe the state's budgetary decisions, it will not be discouraged to make a finding of unreasonableness even if this would have the consequence that the state itself would need to rearrange its budget. ${ }^{95}$

The South African Constitutional Court's take on justiciability is certainly unique. Essentially, the judges created a presumption of the justiciability of socio-economic rights when they stated that "clearly they are" justiciable. ${ }^{96}$ This did not imply however that deference to other branches of government was entirely excluded. Rather, justiciability and its specific scope became a matter to be decided based on the facts of a particular case after having analysed it under methodological and contextual aspects. As one author puts it, the Court thereby determines the "relative justiciability" of each case that comes before it within a certain "justiciability spectrum", resulting in the fact that the intensity of review and the intrusiveness of the Court's orders may vary according to the specific facts at hand. 97

It cannot simply be assumed that other constitutional courts would take as bold a stance on the issue as did the South African judges in Treatment Action Campaign. In many countries, those courts already face criticism for allegedly putting too strong a focus on the

Sandra Liebenberg, South Africa, Adjudicating Social Rights Under a Transformative Constitution, in: Langford, note 89, p. 100.

Ibid, p. 101.

94 Treatment Action Campaign, note 45, para. 38.

Danie Brand, Socio-Economic Rights and Court in South Africa: Justiciability on a Sliding Scale, in: Fons Coomans (ed.), Justiciability of Economic and Social Rights, Experiences from Domestic Systems, Antwerpen 2006, p. 224. 
enforcement of human rights in general. It is being contended that judges nowadays assume too much power by taking far-reaching decisions on politically sensitive matters without being democratically elected and thus lacking a representative mandate. This type of criticism would presumably be exacerbated in relation to the adjudication of socio-economic rights, which is still, up until today, seen by many as inherently political in nature. ${ }^{98}$

\section{Concluding remarks}

For proponents of justiciable socio-economic rights, there is much in the South African jurisprudence to rejoice over, most notably the fact that it has provided this category of rights with the kind of "stories" that depict the impact which they can have on the real-life experiences of individuals. Traditionally, the people and the stories behind human rights cases are one of the factors that drive human rights discourse. As one author puts it, "Drawing attention to the effects of programs and policies on real human beings, rather than beginning with an a priori policy position, has proven to be a tremendous strength of the human rights approach." has achieved just that. Socio-economic rights will forever be associated with the names and fortunes of people like Thiagraj Soobramoney and Irene Grootboom.

Unfortunately, the stories behind the South African jurisprudence have so far not had the happy endings one might hope for. As aforementioned, Mr. Soobramoney died very shortly after the Constitutional Court's judgment in his case was delivered. ${ }^{100}$ Neither did Ms. Grootboom live to see the day that she would obtain social housing. She died in 2008, at the age of 39 , living in the same shack that she had moved to during the Constitutional Court proceedings. ${ }^{101}$ Not even Treatment Action Campaign, the first case in which the Constitutional Court unambiguously ordered government to provide immediate relief to pregnant women with HIV who did not have access to Nevirapine until that point, proved to be the perfect success story. In fact, the government showed great reluctance to distribute antiretroviral medication to all deserving patients and in some provinces, the judgment's

See, however, the development of the socio-economic rights jurisprudence by the Colombian Constitutional Court, which increasingly draws attention; Rodrigo Uprimny Yepes, Should courts enforce social rights? The experience of the Colombian Constitutional Court, in: Coomans, note 95, p. 355. See also Rodolfo Arongo, VRÜ 42 (2009), Nr. 4 (this issue), p. 576.

Alicia Ely Yamin, The Future in the Mirror: Incorporating Strategies for the Defense and Promotion of Economic, Social and Cultural Rights into the Mainstream Human Rights Agenda, Human 100 Rights Quarterly 27 (2005), p. $1215 f$.

Supra, note 32 and corresponding text.

01 Francis Hweshe, 'Heroine' dies while still waiting, 4 August 2008, online: www.abahlali.org/ node/3860. 
orders were only implemented after the initiation of contempt of court proceedings against the relevant provincial authority. ${ }^{102}$ As for the case which is expected to be the next "landmark ruling" in the field of socio-economic rights, the Phiri water case, its first applicant after whom the case is named, Lindiwe Mazibuko, also passed away in 2008 without seeing the end of her vigorous fight against pre-paid water meters. ${ }^{103}$

The human tragedies behind the judicial proceedings before the South African Constitutional Court are deplorable. Unfortunately, it is often in the light of such tragedy that human rights protection burgeons and that we understand its true meaning and value. In South Africa and elsewhere, coming to terms with social and economic suffering remains an ongoing struggle. The Constitutional Court, despite some weaknesses in it decisionmaking on socio-economic rights, has begun to pave a way of how to do so in a judicial context, which, in the end, is all one could ask from it.

Christopher Mbazira, Non-implementation of court orders in socioeconomic rights litigation in 103 South Africa, Is the cancer here to stay?, Economic and Social Rights Rev. 9 (No. 4) (2008), p. 4.

Pambazuka News - Pan-African voices for Freedom and Justice, Obituaries, Lindiwe Mazibuko, the first applicant in the landmark Phiri Water Case, 28 May 2008, Issue 376, online: www. pambazuka.org/en/category/obituary/48405. 